\title{
'n Teoretiese inleiding tot narratiewe hermeneutiek in die teologie ${ }^{1}$
}

\author{
Yolanda Dreyer \\ Departement Praktiese Teologie \\ Universiteit van Pretoria
}

\begin{abstract}
A theoretical introduction to narrative hermeneutics in theology

The premise of this article is that narrative hermeneutics as a method of research in theology departs from a dialectical relationship between hermeneutics and the method of interpretation. The article aims to describe and explain narrative as a "way of knowing". It focuses on the form, content, function and context of myth. Myth is foundational to the lifestories of people and groups. The discussion on narrative theory applies Paul Ricoeur's concept of the "hermeneutical arch" in narrative hermeneutics. The article concludes with the idea that narrative as a way of knowing is ideological critical and deconstructs dominant socio-cultural narratives. The story of Jesus of Nazareth as the foundational myth of the Christian faith community can function as a contra narrative in order to give meaning to people's lives in the presence of God in a postmodern world.
\end{abstract}

\section{INLEIDING}

Waar die kerk staan in die hede en hoe die onsekerhede van die hede ervaar word, het te doen met krisisse in die hede en verlede asook die verwagtings oor die toekoms. Dieselfde onsekerhede word ervaar deur individue, groepe en kulturele instellings (strukture), soos geloofsgemeenskappe. Wanneer die situasie van 'n kerk beskryf en die geskiedenis daarvan ondersoek word met die

\footnotetext{
${ }^{1}$ Hierdie artikel is die eerste deel van 'n studiestuk oor narratiewe hermeneutiek vir die Voortgesette Teologiese Toerusting kursus vir predikante van die Nederduitsch Hervormde Kerk in 2003, "'n Visie vir die Hervormde Kerk op pad na 2010 - 'n Narratief".
} 
oog op insigte vir die hede en toekoms, word die hulp van dissiplines soos die psigologie, sosiologie, ekonomie en antropologie ingeroep. In die mens- en sosiale wetenskappe bestudeer die psigologie die gedrag van en interaksie tussen individue, sosiologie dié van groepe en makrososiologie (antropologie) (kyk Monaghan \& Just 2000:53-74) dié van groepe wat in kulturele strukture funksioneer. Hierdie dissiplines oorvleuel. 'n Kerk as instelling is die kollektiewe begrip wat al drie terreine insluit.

Volgens die praktiese teoloog, Don Browning ([1991] 1996:77), meen sommiges dat die teologie geen aandeel kan hê in die beskrywing van die huidige situasie nie. Teologie het net te doen met die oplossings. Die rede vir hierdie siening is volgens Browning (1996:78) die gebrek aan 'n hermeneutiese verstaan van die taak van beskrywing en historiese ondersoek. In die hermeneutiese benadering kom toepassing nie eers ná ondersoek en beskrywing nie, maar speel 'n rol in die beskrywing van die situasie. Die proses om te verstaan en te interpreteer, speel deurgaans ' $n$ rol in die refleksie oor en vertolking van sosiale instellings se konvensies, etos en identiteit. Teologie as refleksie op die mens coram Deo neem nie 'n plek in náás, ná of vóór die ander mens- en sosiale wetenskappe as "dissiplinêre diskoerse" aan die hand waarvan die hede, verlede en toekoms van die kerk ondersoek, beskryf en verklaar word nie. Hoewel teologie nie psigologie, sosiologie of antropologie is nie ('n modernistiese kompartementalisering), behoort die Aufklärung se dualisme tussen mense se godsbewussyn (vertikale dimensie) en eksistensie (horisontale dimensie) nie die ondersoek te determineer nie.

Die doel van die artikel is om narratief as 'n "kennisweg" (way of knowing) te beskryf en verklaar. Die fokus val op die vorm, inhoud, funksie en konteks van mite as die dieper liggende narratief agter die lewensstories van mense en groepe. In die bespreking van narratiewe teorie word gefokus op Paul Ricoeur se konsep van die "hermeneutiese boog". Die bevinding is dat narratief as 'n kennisweg ideologie-krities is en die dominante sosio-kulturele narratief dekonstrueer. Die "implisiete mite" van die Christelike geloofgemeenskap is 'n 
kontranarratief wat kan sin gee aan mense, sodat hulle outentiek in die teenwoordigheid van God kan bestaan.

\section{WETENSKAPSTEORIE}

Verfynde wetenskapsteoretiese insigte vorm nie altyd die grondslag vir die benutting van ander menswetenskappe in die teologie nie. Teologie is dikwels onkrities ten opsigte van die filosofiese teorieë agter die wetenskaplike metodes en die implisiete waardes van hierdie vakgebiede, in die besonder hoe die waardes van ander dissiplines moontlik kan bots met dié van die teologie (Browning 1996:81). Die hermeneutiese benadering het belangrike implikasies vir die menswetenskappe, omdat alle verstaan 'n vorm van kommunikasie binne histories gesitueerde kontekste is.

Gadamer (1982) wys daarop dat verstaan plaasvind op grond van dialogiese gesprek. Die breër konteks van alle dialoog is die historiese situasie waarbinne dit gebeur. Gadamer (1982:5-7) lig die tekortkominge van die positivisme se induktiewe metode vir die menswetenskappe uit en beklemtoon die noodsaak van 'n hermeneutiese benadering. Die induktiewe metode is ' $n$ produk van die twintigste-eeuse logiese positivisme (vgl Van der Ven 2000:5657). Dit was 'n poging om 'n oplossing te bied vir die probleem dat die ideaal van objektivisme in die wetenskap geblyk het onhaalbaar te wees (vgl Woodson 1979:1). Gadamer se beswaar teen die induktiewe metode is dat ondersoekers afstand skep tussen hulleself en hulle studie-“objek". Hulle probeer ook om 'n afstand te bewaar van die kulturele en godsdienstige tradisies waardeur hulle gevorm is. Gadamer (1982:8) haal Wilhelm Dilthey (kyk Ricoeur 1991:58-63) aan wat sê dat die (modernistiese - YD) wetenskap funksioneer met behulp van "the establishing of a distance from its own history". Hierdie positivistiese benadering wil wetenskaplikes se vooronderstellings en vooroordele, wat in die geskiedenis en deur tradisies gevorm is, probeer uitskakel. Ricoeur (1981:64-65) stel dit soos volg: "The methodology of the sciences ineluctably implies an assumption of distance; and this, in turn, presupposes the destruction of the 
primordial relations of belonging - Zugehörigkeit - without which there would be no relation to the historical as such."

In die positivisme is die veronderstelling dat, as die regte metode van ondersoek ingespan word, die ondersoeker seker kan wees dat die "waarheid" in die ondersoek gevind sal word. Die gevaar is dat metode en waarheid as sinonieme gebruik word. Gadamer het in sy boek, Wahrheit und Methode, dié gevaar uitgelig. Ricoeur stem hiermee saam, maar wys uit dat Gadamer se hermeneutiek daartoe kan lei dat die ondersoeker se vooronderstellings (insluitende mites en lewensnarratiewe) nie genoegsaam aandag kry nie (vgl Browning 1996:82). Volgens Ricoeur (1981:60) werk Gadamer nie die verhouding tussen hermeneutiek (verstaan) en metode verder uit nie. Ricoeur en ander ondersoekers soos Max Weber en James Hopewell het in verskillende werke 'n dialektiese model (metode) ontwerp om die verhouding tussen metode en hermeneutiek (verstaan) te verduidelik.

Max Weber (1949) se sosiologiese model van die "ideële tipe" neem geskiedenis op 'n hermeneutiese wyse in berekening sonder om in empirisme te verval (vgl Monaghan \& Just 2000:64). Volgens Weber (1949:89-112) is 'n ideële tipe 'n teoretiese konstruk wat moontlike gebeure in verband bring met mekaar met die doel om 'n samehangende beeld te vorm van data uit die verlede. ' $n$ Ideële tipe is 'n konseptualisering en sal nie noodwendig ooreenkom met die empiriese werklikheid nie. As 'n konstruk wat 'n eenheidsbeeld wil voorhou, beïnvloed die ideële tipe wel die ondersoek na die verbande tussen historiese gebeure. Hierdie konstruk berus nie op universeel-geldige (postprioriese) aannames op grond van empiriese ondersoek nie. Die ideële tipe funksioneer as 'n (prioriese) model/metode wat in 'n dialektiese verhouding staan tot hermeneutiek (verstaan) en historiese (empiriese) gegewens en vooronderstellings op 'n nie-positivistiese wyse in ag neem. Daarom is dit nie 'n logiespositivistiese keuse gebaseer op 'n induktiewe of deduktiewe beredenering nie. James Hopewell (1987) volg 'n etnografiese benadering tot "simboliese kultuur" in sy boek, Congregation: Stories and structures. Hy kombineer etnografie met die literatuurteorieë van Northrop Frye in sy semiotiese benadering tot 
die studie van kultuur. Etnografie is vir die antropoloog wat laboratoriumwerk is vir die bioloog. "(E)thnography is based on the apparently simple idea that in order to understand what people are up to, it is best to observe them by interacting with them intimately and over an extedend period" (Monaghan \& Just 2000:13 - my beklemtoning). Hiervolgens word kulturele betekenis gesien as 'n konfigurasie van tekens en metafore wat georden word deur 'n struktuur van reëls en kodes. Volgens Browning (1996:124-125) is eksponente van die semiotiek onder andere Clifford Geertz, Roland Barthes, Roman Jacobson en Vladimir Propp. Hopewell steun hoofsaaklik op Geertz (1973), aangevul deur die literatuurteorieë van Frye (1957).

Vir Hopewell is die narratief belangrik vir die verstaan van die ingewikkelde sisteem van tekens, metafore en kodes in kulturele instellings (insluitende groepe soos bv 'n kerk). 'n Narratief is 'n groep se "geskiedenis" wat in verhaalvorm vertel word. Dit is egter ook méér. Dit gee 'n aanduiding van wat die betekenisse is wat die groep aan die gebeure heg. Hopewell verduidelik dat die narratief bestaan uit plot, konteks (setting) en karakterisering. Plot is die storielyn wat die geskiedenis vertel. Die konteks sluit die wêreldbeeld van die groep in wat deur middel van die plot duidelik word. Karakterisering is volgens Hopewell $(1983: 71 ; 1987: 103-107)$ die etos of patroon van waardes van 'n groep. Etos verwys eerder na die hartklop (feel) van 'n groep as na hulle kultureel georiënteerde wêreldbeeld wat meer te doen met verpligting as met visie (Browning 1996:124). Die etos of hartklop van 'n groep spruit voort uit die groep se "implisiete/latente mite" (Hopewell 1987:107-111), met ander woorde uit mense se stories (en die dieper liggende mites agter hierdie stories) eerder as die groep se normatiewe konvensies.

\section{MITETEORIE}

Die godsdienswetenskaplike van Finland, Lauri Honko (1984:49), bespreek miteteorie aan die hand van vier kriteria: vorm, inhoud, funksie en konteks. Die vorm van ' $n$ mite is ' $n$ narratief oor die oorspronge van wat heilig is. Mitiese prototipes (oerfigure wat as rolmodelle funksioneer, asook skeppings- en 
stigtingsgebeure) word in ' $n$ verhaalvorm uitgedruk. Mite as narratief kan van mite as geskiedenis onderskei word deur te kyk na die rol wat herinnering in narratiwiteit speel. Pierre Nora (in Elon 1995:[xvi]) stel dit in sy boek, Les lieux de mémoire, soos volg:

Memory and history are far from being synonymous. They are, in fact, opposites. Memory is life, it is always carried by living people and therefore it is in permanent evolution. It is subject to the dialectics of remembrance and amnesia, unaware of successive deformations and liable to all kinds of uses and manipulation. Memory remains latent for a long time and then suddenly revives .... It always belongs to our own time, a living link with the eternal present.

Mites kan in literêre vorm (enacted myth) of vertelde vorm (narrated myth) uitgedruk word. Mite in die vertelde vorm kom voor in verbale en nie-verbale vorme soos preke, himnes, gebede en danse. Mites word ook uitgebeeld as godsdienstige kuns soos ikone en simbole. Informele vorme van mite is byvoorbeeld denke, drome en gedrag.

Wat inhoud betref, vervul die kosmogoniese komponent die sentrale plek in mites (Honko 1984:50-51). Hierdie mites is narratiewe wat die geboorte en legitimasie van groepe terugvoer na 'n skeppings- of stigtingsgebeure in die oerverlede. Nie alle mites is egter is kosmogonies van aard nie (Honko 1984:50). Heiler (1961:283-286) bied die volgende tipologisering van mites:

- Teogoniese mites: narratiewe oor die oorsprong van die gode.

- Kosmogoniese mites: skeppingsmites, byvoorbeeld waar die wêreld of 'n groep vandaan kom en die onderwerping van chaos.

- Kosmologiese mites: verduidelik "skeppingsordes" in die natuur en die oerbegin (primeval era); dit sluit mites oor die son, sterre en seisoene in. 
- Antropologiese mites: narratiewe oor die skepping van die mens en die mens se verhouding met die gode; dit sluit mites oor sondeval en 'n vernietigende watervloed in.

- Voorouermites: vertellings (dikwels in die vorm van sages) oor die oorsprong van groepe mense soos stamme.

- Kultusmites: oor die oerbegin (primeval origin) van 'n heiligdom of 'n kultiese seremonie/rite.

- Verlossings- en openbaringsmites: stories oor goddelike ingrype in die wêreld van mense deur die optrede van 'n reddersfiguur.

- Jenseitsmythen: narratiewe oor die onderwêreld, hemelreise, die dood en die ewige lewe.

- Eindtydmites: kataklismiese berigte oor die einde van die wêreld en die katastrofale herstel van die oerbegin (primal situation).

In skeppingsmites speel die drie hoof tipes rituele 'n rol: kalenderrites (wat te doen het met seisoene, feestye en die indeling van die week), rites de passage (rituele wat die oorgange van lewensfases merk) en rites van krisis (bv geboorte en dood) (Honko 1984:50). Hulle dien as identiteitsmerkers wat aan mense 'n plek in 'n bepaalde kultuurgroep toeken. Hierdie mites gee in baie godsdienste die gesag aan vertellings oor hoe die bepaalde kultuur (insluitende godsdiensgewoontes) tot stand gekom het. Die ontstaan of radikale vernuwing van godsdienste, asook 'n beslissende verandering in die toekomsvisie en missie van 'n geloofsgroep as gevolg van krisisgebeure in die lewe van die groep, word gewoonlik met narratiewe gelegtimeer waarvan die inhoud ' $n$ herinterpretasie is van bestaande skeppingsmites. In hierdie narratiewe speel elemente van "seisoenveranderings" (kalenderrites), rites de passage en "dood-en-opstanding" rites 'n rol. 
Die funksie van die mite is om as model te dien vir menslike aktiwiteit. Mite verander of ontwikkel nie vanselfsprekend wanneer paradigmas wissel nie. Mites verwys na hoe goddelike kragte en figure uit die verlede as rolmodelle vir latere geslagte dien. Vir die religieuse persoonlikheid word die goddelike werksaamheid van voorgangers (profete, apostels en ander charismatiese figure) die model vir eie denke en gedrag. Een van die funksies van mites is dus om 'n kognitiewe basis te bied vir praktiese modelle van gedrag (kyk Honko 1984:51). Dit geld ook vir 'n kerk.

Die konteks van mite is gewoonlik die ritueel, dit wil sê 'n gedragspatroon wat deur gebruik gesanksioneer is. Daarom voorsien mite die ideologiese inhoud van 'n sakrale vorm van gedrag. Die ritueel bring die skeppingshandeling van die Urzeit in die werklikheid van die hede in. Die alledaagse werklikheid tree op die agtergrond (recedes) en word oorstyg deur (is superceded by) die realiteit van die rituele drama. Wat eens in die Urzeit moontlik was, word weer in die hede moontlik en kan opnuut invloed uitoefen op mense se lewens.

Geloofsgroepe se posisionering ten opsigte van hulle visie en missie vir die toekoms hang dus saam met narratiewe wat gegrond is in latente foundational myths. Hierdie latente, dieper liggende mite het ook die vorm van 'n narratief met die inhoud van 'n storie oor 'n nuwe begin - 'n soort herskepping wat neerkom op 'n "dood-en-opstaan - en het die funksie om as praktiese model vir alledaagse gedrag te dien. In hierdie visie en missie behoort die belang van verandering in kultiese en rituele gebruike, soos liturgie, as die konteks van die "nuwe begin" besef te word .

So 'n "posisionering" van 'n geloofsgemeenskap met die oog op die toekoms behoort daarom nie beskryf en verduidelik te word met rasionele analitiese argumente sonder dat die narratiewe en mitiese karakter van die bepaalde geloofsgemeenskap gehoor en in berekening gebring te word nie. In aansluiting by Jung, skryf Joseph Campbell (1972:13) in sy werk, Myths to live by: "[Myths] are telling us in picture language of powers of the psyche to be recognized and integrated in our lives, powers that have been common to the human spirit forever, and which represent that wisdom of the species by which 
man has weathered the milleniums. Thus they have not been, and can never be displaced by the findings of science, which relate rather to the outside world ...."

Robert A Segal (1999:119-120) wys egter op belangrike verskille tussen Campbell en Jung. Vir Jung is mite die produk van 'n bepaalde kultuur. Agter 'n mite lê 'n universele archetipe. Volgens Campbell is mites self universeel. Hy neem nie in ag dat elke kultuur eie mities vorme sal hê nie (kyk Segal 1999:67-97 vir 'n uiteensetting van sy verstaan van Jung se siening van mitologie). Net soos die klassikus G S Kirk (1984:53-61), maak Segal beswaar teen Campbell se universalistiese en psigologies-simboliese interpretasie van mites (vgl Segal 1999:135-141). Hierdie probleem kan, volgens Segal (1984:262-263), oorkom word as die psigologiese interpretasie van mites die teorieë van historici en antropoloë in ag neem. Die betekenis van mites kan dan meer relatief tot die bepaalde tyd en samelewing waarin dit voorkom, ondersoek word (kyk veral Segal 1980:3-49).

Die insig in relatiwiteit ten opsigte van betekenis, is 'n belangrike uitgangspunt in die hermeneutiese benadering tot tekste - insluitende mites. Jung self beklemtoon hierdie uitgangspunt. Omdat die kollektiewe onbewuste inherent onbewustelik is, is dit "impossible to say what [its content] refers to. Every interpretation necessarily remains an 'as-if'. The ultimate core of meaning may be circumscribed, but not described" (Jung [1959] 1968:156). Hierdie "onuitputlike" en "altyd ontwykende" betekenis van mite is daaraan toe te skryf dat mites "simboliese manifestasies van archetipes" is. Beide die aspekte "simbool" en "archetipe" behoort dus by mite-interpretasie in berekening gebring te word. ' $\mathrm{n}$ Derde faktor is ook belangrik:

Myths [for Jung] do not merely convey meanings. They convey meanings to adherents. Myths are intended by the unconscious to reveal its contents to those whose myths they are. To reach their intended audience, myths must be translated into language the audience knows. Just as archetypes must be translated, however insufficiently, into myths, so myths must be translated, however insufficently, into language of those whose myths they are.

(Segal 1999:72-73) 
Op grond van die narratiewe vorm, die kosmogoniese inhoud, die funksie om as model van gedrag te dien, en die rituele konteks waarin die sekulêre hede deur die sakrale verlede gevul word, het daar in moderne diskoerse 'n aantal teorieë ontwikkel om mites eksistensieel te interpreteer. Honko (1984:46-48) noem twaalf kategorieë:

\section{- $\quad$ Mite as bron vir kognitiewe vraagstelling}

Die intellek het nodig dat bepaalde aspekte van die universum gekonseptualiseer word sodat relasies tussen verskillende verskynsels geskep kan word.

\section{- $\quad$ Mite as 'n vorm van simboliese uitdrukking}

Soos ander skeppende aktitwiteite van die mens, byvoorbeeld poësie en musiek, is mites (wat hulle eie reëls, realiteit en uitdrukkingsvorms het) menslike projeksies om die wêreld simbolies te orden.

\section{- Mite as projeksie van die onbewuste}

Mense funksioneer op ' $n$ bepaalde manier in die alledaagse lewe. Wanneer hierdie gedrag skade berokken aan die persoon self of ander, is mense geneig om die insig dat dit verkeerd is, onbewus te ontken of te onderdruk. Die oorsaak van hierdie "vervalsing" is volgens Jung terug te vind in 'n dieper liggende mite wat die manifestasie is van ' $n$ universele archetipe. Vir Jung is dit nie net neuroses wat hierdie vervalsing veroorsaak nie, maar ook sosiale konvensie en tradisie.

\section{- $\quad$ Mite as wêreldbeeld (paradigma)}

Mites bied ' $\mathrm{n}$ verklaring daarvoor dat individue kan saamstem oor waardes en 'n wêreldbeeld deel. Dit dra daartoe by dat mense binne 'n gedeelde raamwerk kennis kan verwerf en wetenskap kan beoefen. Gedeelde waardes kan egter in 'n ander paradigma as onaanvaarbaar ervaar word. 
- $\quad$ Mite as "ooreenkoms" (charter) van gedrag

Mites bied 'n model vir mense om op 'n sosiaal-aanvaarbare manier uiting te gee aan hulle emosies sonder om ontwrigting te veroorsaak. Mites legitimeer aanvaarbare gedrag deur dit te grond in voorbeelde uit die oerverlede.

- $\quad$ Mite as legitimasie van sosiale instellings

Mites as die onderbou van rites en seremonies, gee uitdrukking aan en konsolideer religieuse waardes waardeur sosiale instellings in stand gehou word.

- Mite as "merker" van sosiale relevansie

Temas wat relevant is vir 'n bepaalde kultuur, word deur mites (die ongeordende versameling van sages en legendes) gedra. ' $n$ Voorbeeld hiervan is dapperheid.

\section{- $\quad$ Mite as spieëlbeeld van kultuur en sosiale struktuur}

'n Kultuur spel nie die waardes waarvolgens dit funksioneer, eksplisiet uit nie.

Mites reflekteer op 'n indirekte wyse die waardes van die kultuur

- $\quad$ Mite as die resultaat/produk van 'n historiese situasie

Die ondersoek na die ontwikkeling van 'n mite vanaf die vorming tot hoe dit later gebruik en verander is deur 'n bepaalde kultuur, dra by tot historiografiese studie.

- $\quad$ Mite as religieuse kommunikasie

Mites as kommunikasie help om die sinvolheid van oënskynlik onnodige herhaling van godsdienstige temas in nie-verbale religieuse kommunikasie in te sien.

\section{- $\quad$ Mite as religieuse genre}

Nie-epiese genres in die godsdiens (bv gebed) kan dieselfde boodskap as narratiewe dra en so help om die mite verprei.

- $\quad$ Mite as medium vir struktuur

Strukturalistiese metodes van eksegese (byvoorbeeld narratologie) kan gebruik word om mites te analiseer. 
Hierdie teorieë kan onderverdeel word in vier subgroepe: historiese, psigologiese, sosiologiese en strukturele perspektiewe. Hoewel daar heelwat oorvleueling is, help die kategorieë die ondersoeker om vanuit verskillende perspektiewe vrae aan dieselfde mite te stel. Elke geloofsgemeenskap, ook die Christelike, funksioneer binne die raamwerk van die vorm, inhoud, funksie en konteks van mite. Agter 'n geloofsgemeenskap lê daar 'n stigtingsmite (foundational narrative). Die verhaal van Jesus van Nasaret behoort die foundational narrative (implisiete mite) van die kerk, elke gemeente en elke Christen te wees. Die sistematiese teoloog McGrath (1990:35) formuleer dit soos volg:

The history of Jesus of Nazareth may be regarded as the precipitating or generative event of Christian doctrine. A community and an associated foundational narrative arose in direct response to that history, which sought to identify and legitimate both the existence of that community as a social entity and its distinctive understanding of God and human nature and destiny with reference to the perceived significance of Jesus of Nazareth.

Die "identiteit" van 'n kerk gaan in die sin dan nie om die verpligting om die tradisies wat die huidige identiteit gevorm het, te handhaaf nie, maar om die verlede, hede en toekoms te bly toets aan die implisiete mite.

Outentieke identiteit (wat behoort te wees) realiseer volgens Heidegger (in Collins \& Selina [1999] 2001:63) nie in Sein nie, maar in Dasein: "It is not I myself who for the most part and on average am my Dasein, but the Others ... Dasein is subject to take-over bids by the Others. It exists as an 'I am' but also as an 'Iam-with-the-Others."' Ricoeur verwys na Heidegger se beklemtoning dat luister konstitutief tot kommunikasie is. Hy formuleer die "ek-vir-ander" interaksie soos volg: "This priority of hearing marks the fundamental relation of speech to the opening toward the world and toward others" (Ricoeur 1991:69). Die kern van die Jesus-verhaal - die kerk se "latente mite"/"foundational narrative" - is om altyd in relasie met ander te wees. John van den Hengel (1994:458-480) het Ricoeur (1992) se insigte oor die "ek-vir-ander" interaksie in die Praktiese Teologie van toepassing gemaak. 


\section{NARRATIEWE TEORIE}

Om vas te stel of 'n geloofsgemeenskap se storie ooreenkom met die kerk se "latente mitiese narratief", kan 'n mens met behulp van 'n narratiewe strategie teruggaan na die plot en konteks van die geloofsgemeenskap se verhaal. Die vraag is: wat lê agter wat mense sê wanneer hulle die eie verhaal van die groep vertel? Wat sê hulle eintlik?

Ricoeur (na aanleiding van Frege 1970:56-78) onderskei tussen die sense of the narrative (signifier/signatum) en die referent of the narrative (signified/designatum). Die sense verwys na die immanente betekenis van die narratief. Dit sluit in die interne sisteem van kodes en reëls wat te doen het met die leksikale betekenis van begrippe, asook die assosiasies wat gepaard gaan met die gewone gebruik van taal. Hy noem dit die sintagmatiese komponent van die verhaal (Ricoeur 1984:56). 'n Narratief het ook 'n referent. Dit is die betekenisse in die narratief wat terugverwys na die verlede en vorentoe projekteer op die toekoms (Ricoeur 1981:171-176, 280-287). Ricoeur (1984:56) verwys hierna as die paradigmatiese komponent van die verhaal. Hierdie verplasing wat tyd betref, is toe te skryf aan die simboliese/metaforiese kwaliteit van "taal as tekens" wat verwysend (referensieel) van aard is en kreatiwiteit in die narratief moontlik maak. Dit gaan verder as die immanente leksikale betekenis van woorde of begrippe.

In postmoderne denke het Jacques Derrida (1972:264; 1976:232; vgl Newton 1988:147) hierdie insigte verfyn met sy begrip difference. Volgens Derrida (kyk Butler 2002:19-21) "verplaas" die een verhaal die ander en die volgende en die volgende .... "Intertextuality is a theory that conceives of every text as a set of relations between texts, an intersection of texts that are themselves intersections of other texts, and so on. Every text is a locus of intersections, overlaps, and collisions between other texts. Every text is an intertext, that is, a between-text (inter, 'between'), a paradoxical locus of dislocation ...." (Beal 2000:128).

Wanneer die een paradigma oorbeweeg na 'n volgende, word konvensionele dinkpatrone volgens Thomas Kuhn (1977: 293-339) uitgedaag en 
disintegreer. Paradigmawisseling is die tyd vir die rekonstruksie van herinnering (Browning 1996:184). Eers word vasgestel hoe die herinnering gevorm is in die verlede. Hiertoe word narratiewe hermeneutiek aangewend. Die beginpunt van die hermeneutiese proses is die huidige praktyke en die betekenisse wat daaraan gekoppel word. Vandaar word phronesis gerig op die tekste én gebeurtenisse in die tekste wat hierdie praktyke voorsien van norme en ideale. Binne Aristoteliese denke is phronesis die refleksiewe aktiwiteit van die ondersoeker. Ondersoekers is betrokke by die teks en die gebeure, norme en ideale waarna die teks verwys. Die leser/hoorder word ingetrek in 'n narratief en die verhaal het die krag om hulle te verander. Dit noem Ricoeur refleksie op die werking van mimesis. Mimesis het te doen met die tekstuur van 'n narratief. Mimesis $_{1}$ of prefigurasie is die aktiwiteit van die outeur of verteller wat 'n teks skep. Die betrokkenheid van die leser/hoorder is mimesis 2 of konfigurasie. Die leser/hoorder se voortgaande lewe as 'n veranderde lewe ('n nuwe teks/nuwe stories) is refigurasie of mimesis $_{3}$.

Hierdie hele proses van mimesis ${ }_{1}$ na mimesis ${ }_{3}$ noem Ricoeur die "hermeneutiese boog" en berus op 'n interpretasie van Aristoteles se Ars Poetica (kyk Ricoeur 1984; vgl 1995:186). Die doel van die hermeneutiek is om uit te kom by refigurasie: dat die leser/hoorder sal kom tot 'n eie nuwe storie. Vertelde karakters se menslike aktiwiteite van lewe, optrede en lyding word deur 'n verteller/outeur op so 'n manier aan die lesers/hoorders gekommunikeer dat dit die lesers/hoorders se eie lewensstorie verander. Die eie lewensstorie verkry sin in interaksie met die stories van ander. Die saak waarmee daar gewerk word, is dus die konkrete proses van konfigurasie as die skarnier tussen die prefigurasie van die handeling van storievertel (activity of narrating/emplotment) en die refigurasie wat plaasvind by die resepsie van die vertelling. Die leser/hoorder is die een wat met die daad van lees/luister die handeling uitvoer wat ' $n$ eenheid skep van mimesis $_{1}$ na mimesis ${ }_{3}$ deur middel van mimesis 2 .

Volgens Ricoeur (1984:52) is daar 'n korrelasie tussen die handeling van storievertel en die temporele aard van menslike ervaring. Die korrelasie is nie toevallig nie, maar 'n transkulturele noodsaaklikheid. Hy stel dit soos volg: 
"[T]ime becomes human to the extent that it is articulated through a narrative mode, and narrative attains its full meaning when it becomes a condition of temporal existence" (Ricoeur 1984:52). Die handelinge van storie vertel en refleksie op die storie het 'n doel. Die doel (toekoms) kan net gesoek word binne die tydraamwerk van mense se lewensstories. Sowel verlede as toekoms is verbind aan die hede. Dit beteken dat die uitkoms (die nuwe lewensstorie) nie vooraf bepaal kan word nie. Deur betrokkenheid by die storie word geboorte gegee aan die toekomsstorie.

In die narratiewe proses word 'n aantal strategieë gevolg. Die motiewe, die redes waarom iemand iets doen of gedoen het, word geïdentifiseer. Wat karakters motiveer, hou nie direk verband met wat gebeur (het) nie. Karakters is agente (aktante - Greimas 1983) wat funksies (soos subjek, objek, helper, protagonis, antagonis) vervul. Agente (soos deur die verteller bepaal) is verantwoordelik vir die gevolge van hulle optrede. Die vraag na motiewe is die "waarom"-vraag. 'n Groot verskeidenheid antwoorde is moontlik. Op die vraag "wie" is die antwoord beperk. Tog kan die waarom- en wie-vrae nie los van mekaar gestel word nie: "To identify an agent and to recognize this agent's motives are complementary operations" (Ricoeur 1984:55). Die agente tree op en ly in spesifieke omstandighede wat nie deur hulleself veroorsaak is nie. Hulle is uitgelewer aan die handelinge van ander en aan gebeurtenisse wat óf 'n gunstige óf ' $n$ ongunstige omgewing skep vir hulle optrede. Handeling is altyd interaksie "met ander". Die interaksie kan óf samewerking behels óf dit kan die vorm van teenstand of stryd aanneem. Die uitkoms van die interaksie kan help of hinder, kan 'n verandering ten goede of ten kwade tot gevolg hê. Die antwoorde op die vrae oor die "wat", "waarom", "wie", "hoe", "met wie" of "teen wie" van ' $n$ handeling is verweef met mekaar en verwys oor en weer na mekaar (Ricoeur 1984:55). In sy bydrae, "Pastoral praxeology, hermeneutics, and identity," verwys Ricoeur ([1989] 1995:306) soos volg hierna: "It is a problem of identity. It seems to me that this is also a problem for those concerned with pastoral ministry inasmuch as there is always the problem of the 'who': Who is the actor? Who intervenes? One intervenes in relation to whom? ... It is in such 
reflection that the word 'return' takes on meaning, as when I speak of returning to myself, that is, of a return to what I am doing, but also to myself, to the self."

Die vraag is: wat sê tradisies en konvensies oor wat gedoen behoort te word? Om die antwoord te vind, behoort die ervaring van mense in die hede ernstig geneem te word. Hulle vertel hulle ervaring, wat beteken dat hulle herinneringe in storievorm weergee. In die vertelling word die rol van konvensies gehoor. Dit kan rigtinggewend of onderdrukkend gewees het. Die rekonstruksie van herinnering (recollection of memory) vra in die narratiewe hermeneutiek 'n ander logika as dié van die positivisme. Ricoeur $(1984: 54,57)$ bou onder andere op die insigte van Ernst Cassirer ([1929] 1955). Volgens Cassirer (kyk Schultz 2000:43; kyk o a Cassirer 1956:169-200) is die abduktiewe epistemologie (kyk Peirce 1957) se uitgangspunt dat kennis relatief is en dat alle tekens in taalhandelinge simbole is. Dit het belangrike implikasies vir narratiewe hermeneutiek. Paul Ricoeur se nie-positivistiese "logiese" redeneerwyse is dieselfde as wat Charles Peirce en Ernst Cassirer abduksie genoem het. Volgens die twaalfde uitgawe van die Van Dale Groot Woordenboek der Nederlandse Taal (Geerts \& Heestermans [1864] 1992) verwys abduksie na 'n "niet strikt logische redeneerwijze, waarmee men een bruikbare hypothese kan verkrijgen." Hierdie wetenskapsbenadering gryp nie soos die deduktiewe en induktiewe epistemologieë terug op bestaande kennis op grond van empiriese waarneming nie. Tog is dit nie wêreldvreemd nie, maar bring ervaring (byvoorbeeld wêreldbeskouing) in berekening. Daar word voortdurend nuwe moontlikhede van verstaan gegenereer. Veral Peirce (1957:236-237; vgl Reilly 1970:30-31, 37; Fann 1970:17-18; Ochs 1998:114-120) het hierdie begrip in die wetenskapsteorie aan die orde gestel. Hierdie insigte het Ricoeur (1976:45-68) gebring tot 'n spesifieke metafoorteorie waarin hy voorkeur gee aan diafoor ("tension theory of metaphor") bo epifoor ("substitution theory") (Ricoeur 1976:55). Deur kommunikasie as 'n diaforiese taalhandeling te sien, word reïfikasie (om 'n mens tot objek te maak) (kyk Schüssler Fiorenza 1999:64) en manipulasie blootgelê en met 'n nie-positivistiese waarheidsbegrip vervang. Ricoeur (1976:68) formuleer hierdie insig soos volg: 
In the case of metaphor, this redescription is guided by the interplay between differences and resemblances that gives rise to the tension at the level of the utterance. It is precisely from this tensive apprehension that a new vision of reality springs forth, which ordinary vision resists because it is attached to the ordinary use of words. The eclipse of the objective, manipulable world thus makes way for the revelation of a new dimension of reality and truth.

\section{BEVINDING}

Ricoeur se insigte met betrekking tot die altyd-kreatiewe "waarheid" van metaforiese taal is in die Bybelwetenskap met groot vrug toegepas op die interpretasie van Jesus se gelykenisse (kyk o a Scott 1981, 1989). Die "spanning" in Jesus se diaforiese stories oor die koninkryk van God is kenmerkend van sy "ervarende bewyssyn" van God se verhaal met mense.

Christene ontmoet God wanneer hulle by hierdie Jesus-verhaal betrokke raak. Om 'n nuwe toekomsverhaal vir die kerk te vertel, is 'n bewustelike proses van soek na die waardes wat Jesus van Nasaret in woord en daad gelewe het en bereid was om voor te sterf. Hierdie waardes word betuig in die Bybel, die kerk se klassieke bron van God se verhaal met mense. Die geloof in Jesus se voortgaande lewe, uitgedruk in die grondliggende mitiese narratief ("die geloofsbelydenis" van die kerk) dat God Jesus uit die dood opgewek het, vertel die verhaal van die geloofsgemeenskap se lojaliteit aan Jesus se evangeliese waardes. Die integrasie van lidmate se lewensstories met die Jesus-verhaal mond uit in die liturgie waar lidmate in hulle liedere, gebede en belydenisse hulle stories oor geboorte-dood, grootword-oudword en krisisse verwoord.

Die stories van mense het ook die karakter van kontranarratiewe. Hierdie protesstories vloei ineen met dié van Jesus en gee geboorte aan 'n "nuwe storie" wat in die lewe "die beste" wil daarstel. In 'n Christelike geloofsgemeenskap is die evangeliese waardes van Jesus riglyne vir wat "die beste" is. In 'n artikel, getitel "Het postmoderne nog eens uitgelegd", verwoord Wim de Pater (1996:201) dit soos volg: 
Het postmodernisme houdt de waarschuwing in dat het christendom niet mag verworden tot een gesloten, hegemonistisch verhaal dat de "gebeurtenis" van het er-aan-komen van nieuwe zinnen uitschakelt omdat alles er al vastligt. Wij worden met andere woorden uitgenodigd het christendom te beleven als een open verhaal dat gangbare verhalen bevrijdend doorbreekt. Dàt was het christendom van oorsprong en intentie, al maakte men er later soms wel wat anders van ... Theologisch betekent het openhouden van verhalen ....

\section{Literatuurverwysings}

Beal, T K 2000. Intertextuality, in Adam, A K M (ed), Handbook of postmodern biblical interpretation, 128-130. St Louis, MS: Chalice Press.

Browning, D S [1991] 1996. A fundamental practical theology: Descriptive and strategic proposals. Minneapolis, MN: Fortress.

Butler, C 2002. Postmodernism: A very short introduction. Oxford: Oxford University Press.

Campbell, J 1972. Myths to live by. New York: Bantam.

Cassirer, E [1929] 1955. The philosophy of symbolic forms, volume III: The phenomenology of knowledge, tr by R Manheim. New Haven, MS: Yale University Press.

Cassirer, E 1956. Der Begriff der symbolischen Form im Aufbau der Geisteswissenschaften, in Cassirer, E, Wesen und Wirkung des Symbolbegriffs, 169-200. Oxford: Bruno Cassirer.

Collins, J \& Selina, H [1999] 2001. Introducing Heidegger. Cambridge: Icon Books.

De Pater, W A 1996. Het postmoderne nog eens uitgelegd. Nederlands Theolo-gisch Tijdschrift 50(3), 177-202.

Derrida, J 1972. Structure, sign, and play in the discourse of the human sciences, in Donato, E \& Macksey, R (eds), The structuralist controversy: The language of criticism and the sciences of man. Baltimore, Va: John Hopkins University Press.

Derrida, J 1976. Of grammatology. Baltimore, Va: John Hopkins University Press.

Elon, A 1995. Jerusalem: Battleground of memory. New York: Kodansha International.

Fann, K 1970. Peirce's theory of abduction. The Hague: Martinus Nijhof.

Frege, G 1970. On sense and reference, tr by M Black, in Geach, P \& Black, M (eds), Translations from the philosophical writings of Gottlob Frege, 56-78. Oxford: Blackwell.

Frye, N 1957. Anatomy of criticism. Princeton, NJ: Princeton University Press. Gadamer, H-G 1982. Truth and method. New York: Crossroad. 
Geerts, G \& Heestermans, H (reds) [1864] 1992. s v abductie. Van Dale Groot Woordenboek der Nederlandse Taal. 12e druk. Utrecht: Van Dale Lexicografie. Geertz, C 1973. The interpretation of culture. New York: Basic Books.

Greimas, A-J 1983. Structural semantics: An attempt at a method, tr by D McDowell, R Schleifer \& A Velie. Lincoln, Nebraska: University of Nebraska Press.

Heiler, F 1961. Erscheinungsformen und Wesen der Religion. Stuttgart: Kohl-hammer. (Die Religionen der Menschheit, Bd. 1.)

Honko, L 1984. The problem of defining myth, in Dundes, A (ed), Sacred narrative: Readings in the theory of myth, 41-52. Berkeley: University of California Press. Hopewell, J 1987. Congregation: Stories and structures. Philadelphia: Fortress Press. Jung, C G [1959] 1968. The archetypes and the collective unconscious. 2nd edition. Princeton, NJ: Princeton University Press.

Kirk, G S 1984. On defining myths, in Dundes, A (ed), Sacred narrative: Readings in the theory of myth, 53-61. Berkeley: University of California Press.

Kuhn, T S 1977. Second thoughts on paradigms, in Kuhn, T S, The essential tension: Selected studies in scientific tradition and change, 293-339. Reprinted from The structure of scientific theories. Chicago: Chicago University Press.

McGrath, A E 1990. The genesis of doctrine: A study in the foundation of doctrinal criticism. Grand Rapids, MI: Eerdmans.

Monaghan, J \& Just, P 2000. Social \& cultural anthropology: A very short introduction. Oxford: Oxford University Press.

Newton, K M (ed) 1988. Twentieth-century literary theory. London: Macmillan.

Ochs, P 1998. Peirce, pragmatism and the logic of Scripture. Cambridge: Cambridge University Press.

Peirce, C 1957. The logic of abduction, in Essays in the philosophy of science. New York: The Liberal Arts Press.

Reilly, F 1970. Charles Peirce's theory of scientific method. New York: Fordham University Press.

Ricoeur, P 1976. Metaphor and symbol, tr by D Pellauer, in Interpretation theory: Discourse and the surplus of meaning, 45-69. Fort Worth, TX: The Texas Christian University Press.

Ricoeur, P 1981. Hermeneutics and the human sciences. Cambridge: Cam-bridge University Press.

Ricoeur, P 1984. Time and narrative, I. London/Chicago: Chigago University Press. 
Ricoeur, P [1989] 1995. Pastoral praxeology, hermeneutics, and identity, in Ricoeur, P 1995, Figuring the sacred: Religion, narrative and imagination, tr by D Pellauer, ed by M I Wallace, 303-315. Minneapolis, MN: Fortress.

Ricoeur, P 1991. The task of hermeneutics, in Ricoeur, P, From text to action: Essays in Hermeneutics, II, tr by K Blamey \& J B Thompson, 53-74. London: Athlone Press.

Ricoeur, P 1992. Oneself as another. London/Chicago: University of Chicago Press.

Ricoeur, P 1995. Figuring the sacred: Religion, narrative and imagination, tr by D Pellauer, ed by M I Wallace. Minneapolis, MN: Fortress.

Schultz, W 2000. Cassirer and Langer on myth: An introduction. New York: Garland Publishing.

Schüssler Fiorenza, E 1999. Rhetoric and ehtic: The politics of biblical studies. Minneapolis, MN: Fortress.

Scott, B B 1981. Jesus, symbol-maker for the Kingdom. Philadelphia, PA: Fortress.

Scott, B B 1989. Here then the parable: A commentary on the parables of Jesus. Minneapolis, MN: Fortress.

Segal, R A [1978] 1984. Joseph's Campbell's theory of myth, in Dundes, A (ed), Sacred narrative: Readings in the theory of myth, 256-269. Berkeley: University of California Press.

Segal, R A 1980. In defense of mythology: The history of modern theories of myth. Annals of Scholarship 1, 3-49.

Segal, R A 1999. Theorizing about myth. Amherst, MS: University of Massachusetts Press.

Van den Hengel, J 1994. Paul Ricoeur's Oneself as another and Practical Theology. ThS 55, 458-480.

Van der Ven, J A 2000. Pastoraal perspectief: Vorming tot reflektief pastoraat. Kampen: Kok. (Theologie \& Empirie.)

Weber, M 1949. Max Weber on the methodology of the social sciences, tr and ed by $\mathrm{E}$ A Shils \& H A Finch. Glencoe, II: Free Press.

Woodson, L 1979. A handbook of modern rhetorical terms. Urbana, II: National Council of Teachers of English. 